\title{
Estimation of Radiation Risk on Public Around Shaheed Suhrawardy Medical College Hospital Campus, Dhaka, Bangladesh
}

\author{
Abdullah Al Shuhan', M. S. Rahman²*, S. Yeasmin'3 , Md. Kabir Uddin Sikder \\ ${ }^{1,4}$ Department of Physics, Jahangirnagar University, Dhaka-1342, BANGLADESH \\ ${ }^{* 2,3}$ Health Physics Division, Atomic Energy Centre, Shahbag, Dhaka-1000, BANGLADESH \\ *(msrahman74@gmail.com)
}

\begin{abstract}
This journal is licensed under a Creative Commons Attribution-Noncommercial 4.0 International License (CC-BY-NC). Articles can be read and shared for noncommercial purposes under the following conditions:

- BY: Attribution must be given to the original source (Attribution)

- NC: Works may not be used for commercial purposes (Noncommercial)

This license lets others remix, tweak, and build upon your work non-commercially, and although their new works must also acknowledge you and be non-commercial, they don't have to license their derivative works on the same terms. License Deed Link: http://creativecommons.org/licenses/by-nc/4.0/

Legal Code Link: http://creativecommons.org/licenses/by-nc/4.0/legalcode

$A B C$ Research Alert uses the CC BY-NC to protect the author's work from misuse.
\end{abstract}

\section{Abstract}

Objective: Ionizing radiation is widely used in the hospital for diagnostic and therapeutic procedures to patients and its usage increasing day by day. The aim of the study is to monitor the real-time radiation around the Shaheed Suhrawardy Medical College (ShSMC) hospital campus and estimation of radiation risk on public.

Method: The real-time radiation monitoring around the ShSMC hospital was performed using digital portable radiation monitoring device (DPRMD). The DPRMD meets all European CE standards and the American "FCC 15 standard". The DPRMD was placed at 1 meter above the ground on tripod and data collection time for each monitoring point (MP) was 1 hour. Each MP was marked out using Garmin eTrex GPS device. 32 MPs were chosen for collection of the real-time radiation dose rates around the ShSMC hospital campus in October 2020.

Results: The real-time radiation dose rates around the ShSMC hospital campus were ranged from 0.37 $3.39 \mu \mathrm{Sv} / \mathrm{hr}$ with an average of $1.537 \pm 0.359 \mu \mathrm{Sv} / \mathrm{hr}$. The annual effective dose on public were ranged from $1.326 \pm 0.551 \mathrm{mSv}$ to $4.902 \pm 0.705 \mathrm{mSv}$ with an average of $2.694 \pm 0.629 \mathrm{mSv}$. The excess life-time cancer risk (ELCR) on public health was estimated based on the annual effective dose that ranged from $5.277 \times 10^{\wedge}-3$ to $19.503 \times 10^{\wedge}-3$ with an average value of $10.72 \times 10^{\wedge}-3$ around the ShSMC hospital campus. Conclusion: Real-time radiation monitoring facilitates to ensure the safety of the radiation workers and the public from undue radiation hazard. The study also gives instant information of improper operation of radiation generating equipments and improper handling of radioactive substances in the hospital.

\section{Keywords}

Ionizing radiation, In-Situ, Hospital, Public, Cancer.

\section{INTRODUCTION}

Ionizing radiation is everywhere and the average annual effective dose per person in the US is about $6.2 \mathrm{mSv}$ (NCRP, 2009). Worldwide average natural background radiation is about $2.4 \mathrm{mSv} / \mathrm{yr}$ (UNSCEAR, 2000). Natural background radiation depends on geological characteristics of a position 
such as altitude, latitude of the place, etc. Public receives ionizing radiation from naturally occurring external gamma emitting radioisotopes. The important gamma emitting naturally occurring radioisotopes are ${ }^{40} \mathrm{~K},{ }^{232} \mathrm{Th} \&{ }^{238} \mathrm{U}$ series with their decay products that exist in soil, water, rocks and construction materials. In-situ gamma-ray dose rate monitoring is very consistent at indoor and outdoor environments (Hazrati S. et al., 2010), (Ateba J. F. B. et al., 2010). Many developed countries with excellent health care system, medical radiation exposures are the main single source of ionizing radiation to public (UNSCEAR, 2008).

Mean radiation dose of the US population has increased twice over the last 30 years (Brenner DJ, 2007; Mettler FA Jr, 2009). Although mean radiation dose at specific location from natural sources has not varied but mean radiation dose from medical imaging has increased 6 times (Brenner DJ, 2007; Mettler FA Jr, 2009). Medical imaging contributes about $50 \%$ of the total radiation dose to the US population comparing to about 15\% in 1980 (Mettler FA Jr, 2009). The highest contributor to this rapidly growth in population exposure in US is the Computed Tomography (CT) scan. Although CT is responsible for majority of the sharp increase in population exposure from medical imaging, other imaging modalities and nuclear medicine procedures are also increasing rapidly, especially in cardiology (Mettler FA Jr, 2009). Radiation exposure of the public resulting from contact with patients undergoing either treatment or a diagnostic procedure that uses sealed and unsealed radionuclides. Radiation exposure of the public also arising from the disposal of radioactive waste from hospitals and the production of radionuclides for medicine (UNSCEAR, 2008).

There are about 3.6 billion diagnostic radiology X-ray examinations undertaken annually in the world (UNSCEAR 2008). Among diagnostic X-ray examinations, CT contributes more radiation to worker \& public and $34 \%$ of collective dose arising from CT examinations alone out of all medical radiation exposures (UNSCEAR, 2000). CT scanning only accounts for $43 \%$ of the total collective effective dose from diagnostic X-ray examinations in the hospital (UNSCEAR, 2008). The ShSMC hospital is situated at the north-western part of Dhaka city and only $1.2 \mathrm{~km}$ away from the Bangladesh National Parliament building. The ShSMC hospital has many departments, namely Surgery, Cardiology, Oncology, Radiology \& Imaging, Dentistry, etc. The objective of the study is to monitor the real-time gamma radiation dose rate around the ShSMC hospital campus following In-Situ Method and estimation of excess life-time cancer risk (ELCR) on public who are residing nearby the ShSMC hospital campus based on the annual effective dose.

\section{MATERIALS AND METHODS}

\section{Description of the monitoring instrument}

A real-time digital portable radiation monitoring device that is called as GAMMA SCOUT was used for the whole study. GAMMA SCOUT is German designed and manufactured, built with a solid Novadur exterior. An optional stylish leather holster with belt strap can further protect the GAMMA SCOUT from the elements. The GAMMA SCOUT is a Geiger counter with a form fitting ergonomic shape. The device has a battery indicator, multiple unit conversion, real-time dose rate and cumulative dose display functions and programmable logging and alert functions. Advanced functions include PC data download via USB cable and an ultra-low current power circuit for extended battery life. GAMMA-SCOUT reports the input of radioactivity fast, reliably, and permanently. The conversion of pulses per minute to dose rate depends on the level of pulse input. We are using four different ratios to approximate this nonlinear relation. Under environmental input (about $0.200 \mu \mathrm{Sv} / \mathrm{h}$ ) the conversion is $142 \mathrm{pulses} /$ minute $=1.0 \mu \mathrm{Sv} / \mathrm{h}$ (User Manual-GAMMA SCOUT, 2014). Gamma-Scout also provides information on the cumulative dose received by the device, measured on the time axis. As described below, users can stop summation, restart from an old level or delete and restart from zero. Because of this and other reasons, the accumulated dose cannot be used as a certified "personal dose meter." GAMMA-SCOUT w/ALERT features can acoustic signal that sounds when the dose rate exceeds a specific level. The default alert level is $5 \mu \mathrm{Sv} / \mathrm{h}$. If this value is exceeded by measurement of radioactivity, this will be shown with an additional symbol in the display. The symbol in the display 
can be erased by pressing the button twice. Individual Programming of Dose Rate Alert Level by pressing the button once to switch to the "log frequency" mode. Pressing the button a second time switches the device to "alert level" mode. The set level shows in the display. Pressing the "or" the button to increase or decrease the threshold respectively. The new value appears blinking in the display. The lowest possible threshold setting is $0.1 \mu \mathrm{Sv} / \mathrm{h}$, the maximum is $2 \mathrm{mSv} / \mathrm{h}$. The step change is 0.1 $\mu \mathrm{Sv} / \mathrm{h}$ at the lower level, becoming wider higher up the range. If the OFF setting is selected, the dose rate alarm is disabled.

\section{Calibration of the monitoring instrument}

In normal environmental radiation, the counter tube is not subject to fatigue and, therefore, will not require re-calibration. But, if the user have ISO certification, periodical calibration is required. To subcontract to an assembly operation, which tests it for 72 hours against a master? The master is calibrated against a gauged reference source (Cs-137). A data log is then produced. To the best of our knowledge, this record is accepted as compliant by ISO auditors without exception.

The GAMMA SCOUT was calibrated inbuilt by the manufacturer. The GAMMA SCOUT is also calibrated at the Secondary Standard Dosimetry Laboratory (SSDL) under the Bangladesh Atomic Energy Commission (BAEC) using gamma-ray standard sources such as ${ }^{137} \mathrm{Cs}$, ${ }^{60} \mathrm{Co}$, etc. and X-ray Unit. The SSDL of BAEC has been available since 1991, which is traceable to the Primary Standard Dosimetry Laboratory (PSDL) of National Physical Laboratory (NPL), UK. The SSDL of BAEC has X-ray Unit $(30 \mathrm{kV}-225 \mathrm{kV})$ for radiation generating equipments calibration. The performance of BAEC's SSDL is maintained according to the requirements of the International Atomic Energy Agency (IAEA)/World Health Organization (WHO) network of SSDLs. Therefore, the evaluated doses are traceable to the International measurement system. The GAMMA SCOUT accurately measures dose rate in the range of $0.01-5000 \mu \mathrm{Sv} / \mathrm{hr}$ (User Manual-GAMMA SCOUT, 2014).

\section{Real-time Radiation Data collection}

The real-time radiation monitoring around the Shaheed Suhrawardy Medical College Hospital ShSMCH) was conducted in October 2020. The real-time radiation monitoring around ShSMCH campus was performed because public receive radiation from the hospital where various types of ionizing radiation generating equipments such as X-ray Machines, CT scanners, Fluoroscopy, etc. used for diagnostic and treatment procedures to patients in every day. The real-time radiation monitoring was performed at 32 selected locations around ShSMCH campus and time for data collection at each monitoring point (MP) was about 1 hour. The GAMMA SCOUT was placed on a tripod at 1 meter height from the ground level. The MP was marked out using a GARMIN eTrex GPS device. The unit uses the proven performance of Garmin high-sensitivity GPS and full-featured mapping to create an unsurpassed portable GPS receiver (Owner's Manual-GARMIN eTrex HC Series, 2007).

\section{Description of the monitoring site}

The study site is located from N: 23.73809 to N: 23.74129 and from E: 090.39332 to E: 90.39937 . The ShSMCH campus has Pre-Clinical Departments (Anatomy, Biochemistry and Physiology), ParaClinical Departments (Community Medicine, Forensic Medicine \& Toxicology, Microbiology, Pathology, Pharmacology \& Therapeutics) and Clinical Departments (Medicine, Physical medicine, Respiratory Medicine, Neuro Medicine, Surgery, Neuro Surgery, Paediatrics, Paediatric Surgery, Paediatric Nephrology, Anesthesiology, ENT, Obstetrics \& Gynecology, Gastroenterology, Urology, Hematology, Blood \& Transfusion Medicine, Radiology \& Imaging, Radiotherapy \& Medical oncology, Dermatology, Burn Plastic \& Reconstructive Surgery, Nephrology, Psychiatry, Cardiology \& CCU, Dentistry, Oral \& Maxillofacial Surgery).

\section{Evaluation of Annual effective dose and ELCR}

United Nations Scientific Committee on the Effects of Atomic Radiation (UNCEAR, 1988) recommended the outdoor occupancy factor of 0.20 to public. This occupancy factor is the proportion 
of the total time during which an individual is exposed to a radiation at outdoor. The outdoor annual effective dose to public due to ionizing radiation is calculated by the equation below:

$$
\text { Annual effective dose }(\mu S v)=\text { dose rate }\left(\mu S v \cdot \mathrm{hr}^{-1}\right) \times 0.2 \times 8760 \mathrm{hr} . \mathrm{yr}^{-1}
$$

Excess life-time cancer risk factor (ELCR) is calculated by the equation below:

$$
E L C R=A E D \times D L \times R F
$$

Where AED is annual effective dose to public, DL is the duration of life of Bangladeshi people (http://en.worldstat.info/Asia/Bangladesh, 2021) and RF is the risk factor $\left(\mathrm{Sv}^{-1}\right)$, it is a fatal cancer risk per Sievert. For stochastic effects from low dose radiation, ICRP 103 suggested the value of 0.057 for the public exposure (ICRP, 2007).

\section{RESULTS AND DISCUSSION}

The real-time measured radiation dose rate around the ShSMCH campus ranged from 0.37-3.39 $\mu \mathrm{Sv} / \mathrm{hr}$ with an average of $1.537 \pm 0.359 \mu \mathrm{Sv} / \mathrm{hr}$. The annual effective dose on public around the ShSMCH campus were ranged from $1.326 \pm 0.551 \mathrm{mSv}$ to $4.902 \pm 0.705 \mathrm{mSv}$ with an average of $2.694 \pm 0.629$ $\mathrm{mSv}$. The real-time radiation monitoring around the hospital would help to ensure the safety of the radiation worker, public \& the patients and also gives an instant signal of inaccurate use of technical parameters of radiation generating equipments or equipment malfunction. Furthermore, the real-time radiation monitoring is also required for calculation of optimum shielding against ionizing radiation that prevent the scattered radiation. The radiation worker \& public received maximum ionizing radiation dose from the scattered radiation in the hospital. Table- 1 shows the real-time radiation dose rate

\begin{tabular}{|c|c|c|c|c|c|c|}
\hline \multirow{2}{*}{$\begin{array}{l}\text { Sl. } \\
\text { No. }\end{array}$} & \multirow[t]{2}{*}{ Latitude } & \multirow[t]{2}{*}{ Altitude } & \multicolumn{3}{|c|}{ Radiation dose rate $(\mu \mathrm{Sv} / \mathrm{hr})$} & \multirow{2}{*}{$\begin{array}{c}\text { Annual effective dose } \\
\text { due to radiation } \\
(\mathrm{mSv}) \pm \mathrm{SD}\end{array}$} \\
\hline & & & Mean & Range & SD & \\
\hline 1. & $\mathrm{~N} 23^{0} 44.472^{\prime}$ & E90 $23.751^{\prime}$ & 0.184 & $0.100-0.260$ & 0.049 & $0.323 \pm 0.085$ \\
\hline 2. & $\mathrm{~N} 23^{0} 44.476^{\prime}$ & E90 $23.735^{\prime}$ & 0.150 & $0.100-0.230$ & 0.033 & $0.263 \pm 0.058$ \\
\hline 3. & $\mathrm{~N} 23^{0} 44.480^{\prime}$ & E $90^{\circ} 23.720^{\prime}$ & 0.169 & $0.100-0.230$ & 0.040 & $0.294 \pm 0.071$ \\
\hline 4. & $\mathrm{~N} 23^{0} 44.475^{\prime}$ & E $90^{0} 23.705^{\prime}$ & 0.209 & $0.140-0.300$ & 0.048 & $0.365 \pm 0.084$ \\
\hline 5. & $\mathrm{~N} 23^{0} 44.475^{\prime}$ & E $90^{0} 23.690^{\prime}$ & 0.191 & $0.120-0.270$ & 0.046 & $0.334 \pm 0.080$ \\
\hline 6. & $\mathrm{~N} 23^{0} 44.470^{\prime}$ & E $90^{0} 23.663^{\prime}$ & 0.162 & $0.070-0.250$ & 0.057 & $0.284 \pm 0.099$ \\
\hline 7. & $\mathrm{~N} 23^{0} 44.464^{\prime}$ & E $90^{0} 23.646^{\prime}$ & 0.162 & $0.100-0.230$ & 0.041 & $0.283 \pm 0.073$ \\
\hline 8. & $\mathrm{~N} 23^{0} 44.466^{\prime}$ & E $90^{0} 23.642^{\prime}$ & 0.168 & $0.100-0.230$ & 0.041 & $0.295 \pm 0.073$ \\
\hline 9. & $\mathrm{~N} 23^{0} 44.311^{\prime}$ & E $90^{\circ} 23.751^{\prime}$ & 0.195 & $0.100-0.300$ & 0.060 & $0.343 \pm 0.105$ \\
\hline 10. & $\mathrm{~N} 23^{0} 44.345^{\prime}$ & E $90^{0} 23.757^{\prime}$ & 0.165 & $0.100-0.230$ & 0.042 & $0.289 \pm 0.073$ \\
\hline 11. & $\mathrm{~N} 23^{0} 44.374^{\prime}$ & E $90^{\circ} 23.743^{\prime}$ & 0.185 & $0.110-0.260$ & 0.048 & $0.324 \pm 0.083$ \\
\hline 12. & $\mathrm{~N} 23^{0} 44.389^{\prime}$ & E $90^{\circ} 23.754^{\prime}$ & 0.166 & $0.100-0.240$ & 0.044 & $0.292 \pm 0.077$ \\
\hline 13. & $\mathrm{~N} 23^{\circ} 44.410^{\prime}$ & E90 $23.758^{\prime}$ & 0.135 & $0.080-0.190$ & 0.036 & $0.237 \pm 0.063$ \\
\hline 14. & $\mathrm{~N} 23^{0} 44.432^{\prime}$ & E $90^{\circ} 23.777^{\prime}$ & 0.130 & $0.080-0.180$ & 0.033 & $0.228 \pm 0.058$ \\
\hline 15. & $\mathrm{~N} 23^{0} 44.453^{\prime}$ & E $90^{0} 23.772$ & 0.199 & $0.110-0.320$ & 0.060 & $0.348 \pm 0.106$ \\
\hline 16. & $\mathrm{~N} 23^{\circ} 44.461^{\prime}$ & E $90^{\circ} 23.762^{\prime}$ & 0.126 & $0.060-0.200$ & 0.044 & $0.222 \pm 0.077$ \\
\hline 17. & $\mathrm{~N} 23^{0} 44.442^{\prime}$ & E $90^{\circ} 23.619^{\prime}$ & 0.184 & $0.050-0.300$ & 0.073 & $0.322 \pm 0.128$ \\
\hline 18. & $\mathrm{~N} 23^{0} 44.424^{\prime}$ & E $90^{0} 23.625^{\prime}$ & 0.161 & $0.020-0.310$ & 0.078 & $0.282 \pm 0.137$ \\
\hline 19. & $\mathrm{~N} 23^{0} 44.410^{\prime}$ & E $90^{0} 23.632^{\prime}$ & 0.199 & $0.050-0.350$ & 0.076 & $0.348 \pm 0.133$ \\
\hline 20. & $\mathrm{~N} 23^{0} 44.385^{\prime}$ & E $90^{0} 23.626^{\prime}$ & 0.166 & $0.090-0.250$ & 0.049 & $0.290 \pm 0.085$ \\
\hline 21. & $\mathrm{~N} 23^{0} 44.369^{\prime}$ & E $90^{0} 23.622^{\prime}$ & 0.181 & $0.100-0.270$ & 0.052 & $0.316 \pm 0.090$ \\
\hline 22. & $\mathrm{~N} 23^{0} 44.358^{\prime}$ & E $90^{0} 23.632^{\prime}$ & 0.185 & $0.100-0.270$ & 0.053 & $0.324 \pm 0.094$ \\
\hline 23. & $\mathrm{~N} 23^{0} 44.349^{\prime}$ & E $90^{\circ} 23.635^{\prime}$ & 0.160 & $0.110-0.210$ & 0.033 & $0.280 \pm 0.058$ \\
\hline
\end{tabular}
measurement around the ShSMCH campus in October 2020 at 32 locations. 


\begin{tabular}{|c|c|c|c|c|c|c|}
\hline 24. & $\mathrm{~N} 23^{\circ} 44.346^{\prime}$ & E $90^{\circ} 23.635^{\prime}$ & 0.190 & $0.110-0.270$ & 0.050 & $0.333 \pm 0.088$ \\
\hline 25. & $\mathrm{~N} 23^{0} 44.307^{\prime}$ & E90023.643' & 0.179 & $0.070-0.340$ & 0.087 & $0.314 \pm 0.153$ \\
\hline 26. & $\mathrm{~N} 23^{0} 44.302^{\prime}$ & E $90^{0} 23.658^{\prime}$ & 0.165 & $0.080-0.250$ & 0.053 & $0.289 \pm 0.094$ \\
\hline 27. & $\mathrm{~N} 23^{\circ} 44.299^{\prime}$ & E $90^{\circ} 23.672^{\prime}$ & 0.170 & $0.060-0.320$ & 0.074 & $0.298 \pm 0.129$ \\
\hline 28. & $\mathrm{~N} 23^{0} 44.287^{\prime}$ & E $90^{0} 23.691^{\prime}$ & 0.302 & $0.080-1.480$ & 0.390 & $0.528 \pm 0.684$ \\
\hline 29. & $\mathrm{~N} 23^{0} 44.284^{\prime}$ & E $90^{\circ} 23.712^{\prime}$ & 0.166 & $0.100-0.240$ & 0.043 & $0.290 \pm 0.076$ \\
\hline 30. & $\mathrm{~N} 23^{0} 44.290^{\prime}$ & E $90^{0} 23.716^{\prime}$ & 0.140 & $0.050-0.230$ & 0.056 & $0.245 \pm 0.099$ \\
\hline 31. & $\mathrm{~N} 23^{\circ} 44.291^{\prime}$ & E $90^{\circ} 23.736^{\prime}$ & 0.155 & $0.080-0.230$ & 0.048 & $0.272 \pm 0.083$ \\
\hline 32. & $\mathrm{~N} 23^{0} 44.309^{\prime}$ & E 90 23.742' & 0.210 & $0.090-0.380$ & 0.082 & $0.368 \pm 0.144$ \\
\hline
\end{tabular}

Table 1: Real-time radiation dose rate monitoring around the ShSMC hospital campus in October 2020

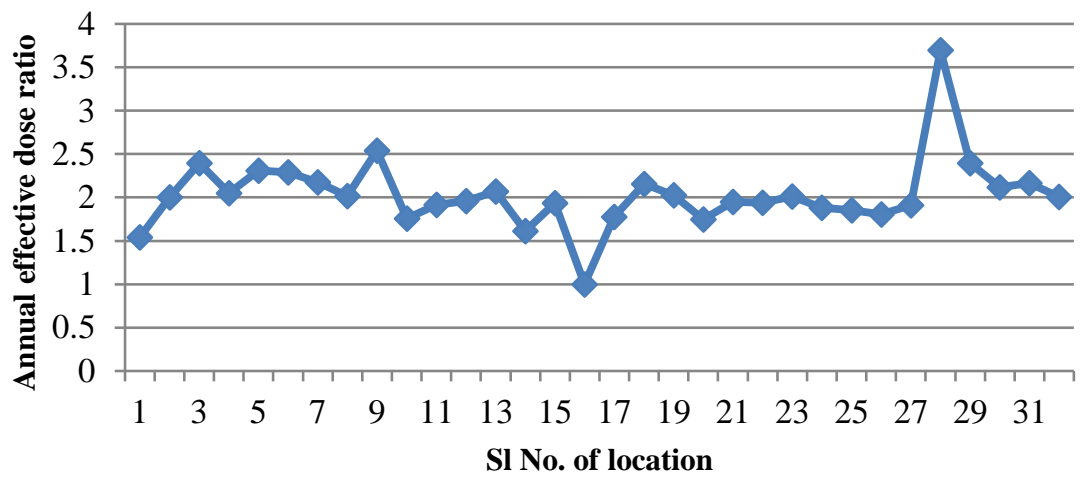

Fig. 1: Annual effective dose values normalized to the minimum annual effective dose for each MP.

The frequency of the dose rate $(\mathrm{nSv} / \mathrm{hr})$ distribution around the ShSMC hospital campus in October 2020 is shown in Fig.2.

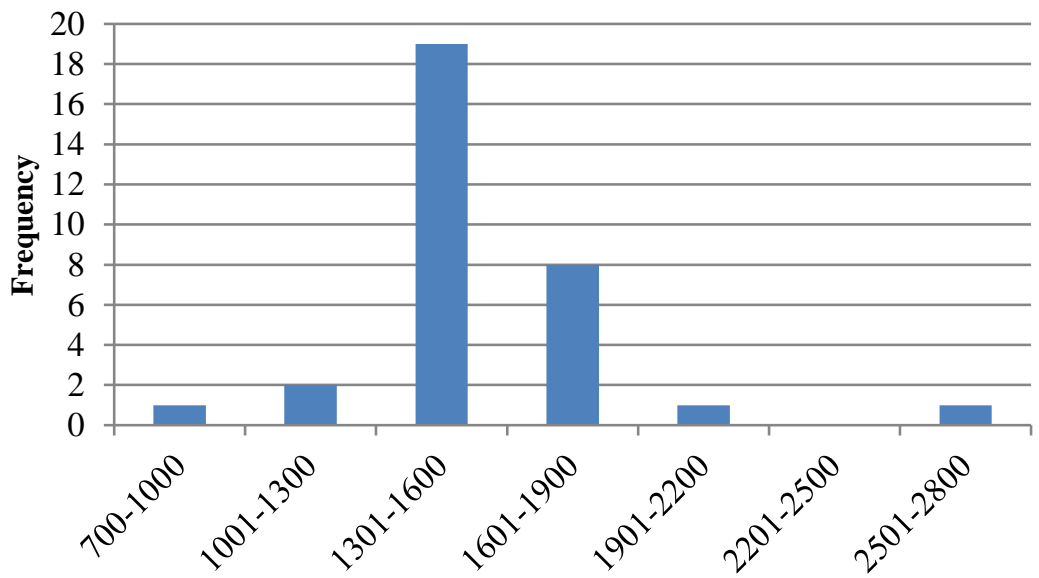

Absorbed dose rate (nSv/hr)

Fig. 2: The frequency of the dose rate (nSv/hr) distribution around the ShSMC hospital campus in October 2020

The term 'Excess life-time cancer risk' (ELCR) is defined as the probability that an individual will develop cancer over his life-time of exposure to ionizing radiation.

ELCR on public around the ShSMCH campus based on the annual effective dose is shown in Fig. 3. 


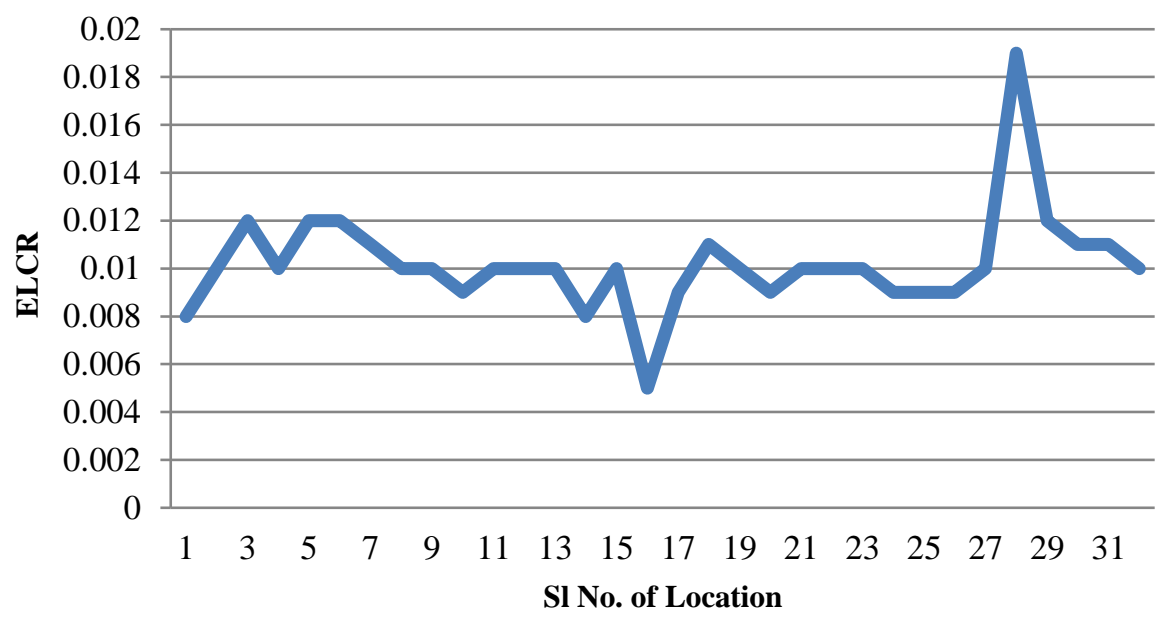

Fig. 3: ELCR on public around the ShSMC hospital campus based on annual effective dose.

From the Table 1, we can observe that mean annual effective dose on public around the ShSMCH campus is $2.694 \pm 0.629 \mathrm{mSv}$. The annual effective dose limit for public is $1 \mathrm{mSv}$ and this limit is applicable for planned exposure situation (ICRP, 2007; NSRC Rules, 1997). The ELCR on public around the ShSMCH campus were ranged from $5.277 \times 10^{\wedge}-3$ to $19.503 \times 10^{\wedge}-3$ with an average of 10.72 $\times 10^{\wedge}-3$. The average ELCR on public around the ShSMCH campus is higher than the average worldwide value of $0.291 \times 10^{\wedge}-3$. The mean ELCR on public around the ShSMCH campus means that in every thousand people, ten of them are at the risk of cancer caused by the scattered radiation exposure from the hospital without any knowledge of being exposed to ionizing radiation. The progress of cancer due to ionizing radiation from the hospital radiation is not an instant effect. It may take many years to develop cancer if it develops at all. It is found in literature (Temaugee et al, 2014) that after exposure to ionizing radiation, cancer may occur with some increasing frequency and can only be detected by epidemiological study. The period between ionizing radiation exposure and the detection of cancer is known as the latent period and this could take many years. The cancer may occur only when the individual has reached an advanced age for maximum cases. The term 'excess life-time cancer risk' (ELCR) is therefore defined as the probability that an individual will develop cancer over his life-time of exposure to ionizing radiation.

\begin{tabular}{|c|c|c|c|c|c|c|}
\hline $\begin{array}{l}\text { Name of } \\
\text { hospital/ } \\
\text { Nuclear } \\
\text { Facility }\end{array}$ & $\begin{array}{c}\text { Range } \\
(\mu \mathrm{Sv} / \mathrm{hr})\end{array}$ & $\begin{array}{c}\text { Mean dose } \\
\text { rate }(\mu \mathrm{Sv} / \mathrm{hr})\end{array}$ & $\begin{array}{c}\text { Annual } \\
\text { range/Mean an- } \\
\text { nual effective } \\
\text { dose }(\mathrm{mSv})\end{array}$ & $\begin{array}{c}\text { ELCR } \\
\mathrm{X} 10^{\wedge}-3\end{array}$ & Country & Reference \\
\hline $\begin{array}{l}\text { Bangabandhu } \\
\text { Sheikh Mujib } \\
\text { Medical Uni- } \\
\text { versity }\end{array}$ & $\begin{array}{l}0.02- \\
3.15\end{array}$ & $1.45 \pm 0.88$ & $\begin{array}{c}0.12-5.44 / \\
2.54 \pm 1.56\end{array}$ & $0.4-20.0$ & Bangladesh & $\begin{array}{l}\text { Hassan F et } \\
\text { al., } 2020\end{array}$ \\
\hline $\begin{array}{l}\text { Dhaka Medi- } \\
\text { cal College } \\
\text { Hospital }\end{array}$ & $\begin{array}{l}0.02- \\
0.58\end{array}$ & $0.17 \pm 0.04$ & $\begin{array}{c}0.21-.43 / \\
0.31 \pm 0.10\end{array}$ & $\begin{array}{c}0.84- \\
1.83\end{array}$ & Bangladesh & $\begin{array}{l}\text { Mim FS et } \\
\text { al., } 2020\end{array}$ \\
\hline $\begin{array}{l}\text { Teaching Hos- } \\
\text { pital }\end{array}$ & - & - & $0.03-0.32$ & - & Nigeria & $\begin{array}{l}\text { Edith N I et } \\
\text { al., } 2018\end{array}$ \\
\hline $\begin{array}{l}\text { Rajasthan } \\
\text { Atomic Power } \\
\text { Station }\end{array}$ & - & - & $0.63 \pm 0.15$ & - & India & \multirow{3}{*}{$\begin{array}{l}\text { Chougaon- } \\
\text { kar M P et } \\
\text { al., } 2008\end{array}$} \\
\hline $\begin{array}{l}\text { Kakrapar } \\
\text { Atomic Power } \\
\text { Station }\end{array}$ & - & - & $0.53 \pm 0.08$ & - & India & \\
\hline $\begin{array}{l}\text { Narora } \\
\text { Atomic Power } \\
\text { Station } \\
\end{array}$ & - & - & $1.2 \pm 0.12$ & - & India & \\
\hline
\end{tabular}




\begin{tabular}{|c|c|c|c|c|c|c|}
\hline $\begin{array}{l}\text { Kaiga Gener- } \\
\text { ating Station }\end{array}$ & - & - & $0.51 \pm 0.11$ & - & India & \\
\hline $\begin{array}{l}\text { Nuclear Estab- } \\
\text { lishment }\end{array}$ & $\begin{array}{c}0.11- \\
0.21\end{array}$ & $0.15 \pm 0.03$ & $0.15-0.30$ & - & Nigeria & $\begin{array}{l}\text { Oyeyinka O } \\
\mathrm{D} \text { et al., } \\
2012\end{array}$ \\
\hline $\begin{array}{l}\text { Nuclear Instal- } \\
\text { lations }\end{array}$ & $\begin{array}{l}0.14- \\
0.27\end{array}$ & $0.19 \pm 0.05$ & $0.19-0.38$ & - & Ghana & $\begin{array}{l}\text { Amekudzie } \\
\text { A et al., } \\
2011\end{array}$ \\
\hline $\begin{array}{l}\text { University of } \\
\text { Port Harcourt } \\
\text { Teaching Hos- } \\
\text { pital, Rivers } \\
\text { State }\end{array}$ & $\begin{array}{l}0.08- \\
0.20\end{array}$ & - & $0.31 \pm 0.002$ & $\begin{array}{c}0.46- \\
1.09\end{array}$ & Nigeria & $\begin{array}{l}\text { Ononugbo } \\
\text { C.P. et al., } \\
2016\end{array}$ \\
\hline $\begin{array}{l}\text { Nuclear Instal- } \\
\text { lation }\end{array}$ & $\begin{array}{l}0.05- \\
0.32\end{array}$ & $0.11-0.19$ & $0.14-0.24$ & - & Bangladesh & $\begin{array}{l}\text { Moontaha S } \\
\text { et al., } 2018\end{array}$ \\
\hline \multirow[t]{2}{*}{$\begin{array}{l}\text { Kwali General } \\
\text { Hospital }\end{array}$} & $\begin{array}{l}0.10- \\
0.12\end{array}$ & $0.108 \pm 0.003$ & $0.189 \pm 0.005$ & - & Nigeria & $\begin{array}{l}\text { James I.U. } \\
\text { et al., } 2015\end{array}$ \\
\hline & - & 0.274 & 0.48 & 0.29 & $\begin{array}{l}\text { Worldwide } \\
\text { average }\end{array}$ & $\begin{array}{l}\text { UNSCEAR, } \\
2008\end{array}$ \\
\hline $\begin{array}{l}\text { Shaheed } \\
\text { Suhrawardy } \\
\text { Medical Col- } \\
\text { lege Hospital }\end{array}$ & $\begin{array}{l}0.37- \\
3.39\end{array}$ & $1.53 \pm 0.35$ & $\begin{array}{c}1.32-4.90 / \\
2.69 \pm 0.62\end{array}$ & $\begin{array}{l}5.27- \\
19.50\end{array}$ & Bangladesh & This study \\
\hline
\end{tabular}

Table 2: Comparison of dose rate, annual effective dose \& ELCR on public around the ShSMC hospital with other authors.

\section{CONCLUSION}

The real-time radiation dose rate is a very important parameter to control the quality of the CT scanners, $\mathrm{X}$-ray machines, PET-CT scanners, linear accelerator and many other radiations generating equipments in the hospital. The real-time radiation monitoring would help to ensure the safety of the radiation worker, public and the patients from unnecessary radiation hazard. The real-time radiation monitoring is an instant signal of inaccurate use of technical parameters of the radiation generating equipments or equipments malfunction. The estimated annual effective dose to public around the ShSMC hospital is higher than that of the worldwide average. It is observed from the study that in every thousand people, ten of them are at the risk of cancer caused by the scattered radiation exposure from the hospital without any knowledge of being exposed to ionizing radiation. The real-time ionizing radiation monitoring and estimation of radiation hazard around the nuclear \& radiological facilities have become great concern for the protection of public and the environment.

\section{Acknowledgement}

This research is funded by the Ministry of Science and Technology, Government of Bangladesh under the Special Research Allocation Project 2019-2020 \& 2020-2021 (the grant serial no. 523 MS \& 519 MS).

\section{REFERENCE}

Amekudzie A., Emi-Reynolds G., Kpeglo D.O., Mensah C.K., Gyekye P.K., Lawluvi H., Gbormittah S.V., Owusu E. (2011) "Determination of dose rate levels around nuclear installations in Ghana", International Journal of Science and Technology, Vol.1(3), pp144-147.

Ateba J.F.B., Ateba P.O., Ben-Bolie G.H., Abiama P.E., Abega C.R., Mvondo S. (2010) "Natural background dose measurements in South Cameroon," Radiation Protection Dosimetry, Vol.140(1), pp 81-88. https://doi.org/10.1093/rpd/ncq035

Brenner DJ, Hall EJ. (2007) "Computed tomography: an increasing source of radiation exposure", N. Engl. J. Med., Vol. 357(22), pp.2277-2284.

Chougaonkar M.P., Shetty P.G., Mayya Y.S., Puranik V.D., Joshi M.L., Kushwaha H.S. (2008) "Environmental gamma radiation monitoring around nuclear power stations in India, An Indian Scenario", Journal of Nuclear Science and Technology, Supplement 5, pp 619-622.

Edith N. I., Philomina O.C. (2018) "Estimation of radiation dose rate of radiological unit personnels in some teaching hospitals in Southern Nigeria", Radiation Science and Technology, Vol. 4(4), pp22-28. 
Hassan F., Rahman M. S., Tareq S. M., Yeasmin S. (2020) “Assessment of Environmental Radiation Hazard on Public Health around BSMMU Campus, Dhaka, Bangladesh”, ABC Research Alert, Vol. 8(1), pp. 09-15.

Hazrati S., Sadeghi H., Amani M., Alizadeh B., Fakhimi H., Rahimzadeh S. (2010) "Assessment of gamma dose rate in indoor environments in selected districts of Ardabil Province, Northwestern Iran", International Journal of Occupational Hygiene, Vol.2(1), pp 42-45.

ICRP (2007), "Recommendations of the ICRP: Annals of the ICRP (International Commission on Radiological Protection)", Vol. 37, pp.2-4.

James I.U., Moses I.F., Vandi J.N., Ikoh U.E. (2015) "Measurement of indoor and outdoor background levels of Kwali General Hospital, Abuja", J. Appl. Sci. Environ. Manage., Vol. 19(1), pp89-93.

Mettler F.A. Jr., Bhargavan M., Faulkner K., et al. (2009) "Radiologic and nuclear medicine studies in the United States and worldwide: frequency, radiation dose, and comparison with other radiation sources-1950-2007", Radiology, Vol. 253(2), pp520-531.

Mim F. S., Rahman M. S., Tareq S. M., Yeasmin S.(2020), “Assessment of Radiation Hazard on Public Health at Indoor and Outdoor Environment of DMCH Campus, Dhaka, Bangladesh”, ABC Research Alert, Vol. 8(2), pp. 69-77.

Moontaha S., Rahman M.S., Islam M.S., Yeasmin S. (2018) "Real-time environmental gamma radiation dose rate measurement around major nuclear and radiological facilities in Bangladesh", International Journal of Scientific Research and Management, Vol. 6(3), pp39-49.

NSRC (1997), (The Nuclear Safety and Radiation Control) Rules of Bangladesh (SRO No. 205-Law/97).

NCRP (2009), the National Council on Radiation Protection \& Measurements, Report No. 160, Bethesda,MD 208143095, USA.

Ononugbo C., Avwiri O. G. (2016) "Evaluation of effective dose and excess lifetime cancer risk from indoor and outdoor gamma dose rate of university of Port Harcourt Teaching Hospital, Rivers State," Scientia Africana, Vol. 15(1). https://www.ajol.info/index.php/sa/article/view/156472

Owner's Manual, GARMIN eTrex HC Series, available at https://static.garmincdn.com/pumac/eTrexLege dHCx_OwnersManual.pdf

Oyeyinka O.D., James I.U., Akueche E.C., Shonowo O.A., Adesanmi C.A. (2012) "Estimation of radiation dose rate levels around a nuclear establishment in Abuja, North Central, Nigeria”, Science and technology, Vol. 2(6), pp 163-167.

Shaheed Suhrawardy Medical College Hospital (ShSMCH), website, http://www.shsmc.gov.bd/sample-page/ (accessed 05 January, 2021)

Temaugee S. T., Daniel T. A., Oladejo K. O., Daniel S. (2014) “Assessment of Public Awareness of the Detrimental Effects of Ionizing Radiation in Kontagora, Niger State”, Nigeria”, International Journal of Science and Technology, Vol. 4(7), pp.134-141.

UNSCEAR (2000), "United Nations Scientific Committee on the Effects of Atomic Radiation. Sources and Effects of Ionizing Radiation Report to General Assembly, with Scientific Annexes (New York: United Nations, United Nations Sales Publication E.00.IX.3).

UNSCEAR (2008), "United Nations Scientific Committee on the Effects of Atomic Radiation. Sources and Effects of Ionizing Radiation Report to General Assembly, with Scientific Annexes, Vol. I, Annex-A, Page No. 23 (New York: United Nations)

UNSCEAR (1993), "United Nations Scientific Committee on the Effects of Atomic Radiation Sources and Effects of Ionizing Radiation Report to General Assembly, with Scientific Annexes (New York: United Nations).

UNSCEAR (1988), "United Nations Scientific Committee on the Effects of Atomic Radiation, sources, effects and risks of ionizing radiation", (United Nations, New York).

User Manual GAMMA SCOUT, available at https://www.gamma-scout.com/EN/Handbuch.php

Web address: http://en.worldstat.info/Asia/Bangladesh (accessed 30 August 2019) 